\title{
PEMANTAUAN BAHAYA KEKERINGAN DI KABUPATEN INDRAMAYU
}

\author{
Monitoring Hazard of Drought in Indramayu
}

\author{
Nina Widiana Darojati1)*, Baba Barus'2), dan Euis Sunarti3) \\ 1) Pusat Pengkajian Perencanaan Wilayah, Lembaga Penelitian dan Pengabdian Masyarakat IPB, Jl. Raya Pajajaran \\ Kampus IPB Baranangsiang, Bogor \\ 2) Departemen Ilmu Tanah dan Sumberdaya Lahan, Fakultas Pertanian, J1. Meranti Kampus IPB Dramaga, Bogor \\ 16680 \\ 3) Departemen Ilmu Kesejahteraan Keluarga, Fakultas Ekologi Manusia, J1. Kamper Kampus IPB Dramaga, Bogor \\ 16680
}

\begin{abstract}
The drought as a natural event and attacked slowly. Drought as a natural event and attacked slowly, has caused harm to the farmers in the district Indramayu. In vew of the drought is an event that can be repeated, it is necessary to monitor and identify factors associated risk of drought, so as to develop a model of the hazard of drought. Besides, it should be made maps to be known distribution of drought useful for the development of agriculture and other policies, as well as to minimize losses that may in the future. This research used a method to identify factors associated risk of drought and develop models of drought. Each factor was scored and weighted in order of importance or influence on the risk of drought and then overlay is connected through the MCE method (Multi Criteria Evaluation). The model is applied to three (3) points in that 2003, 2008 and 2012. The model is built for two versions. Model version 1, implementaed by excluding the distance from the irrigation network and model version 2, include a range of irrigation networks. The results showed that the drought hazard factor that has the most impact to the lowest is the rainfall, land use, distance to water sources, soil texture, soil surface temperature, in order to obtain a model with the formulation: $H=(0.34 S P I)+(0.20 \mathrm{~L})+(0.19 \mathrm{~B})+(0.17 \mathrm{Jt})+(0.10 \mathrm{LST})$. The spread of the hazard on the model version 2 has an area at risk of drought less than the model version 1 and version 2 have a value lower accuracy than version 1. Model version 2 is an ideal condition, however, irrigation is less a role during the dry season. Meanwhile, the model version 1 has a significant level of validation. Version 1 is a condition close to the real situation on the ground.
\end{abstract}

Keywords: Drought, hazard, land surface temperature, multi criteria evaluation, Standar Presipitation Index

\section{ABSTRAK}

Kekeringan sebagai peristiwa alam dan menyerang secara perlahan, telah menimbulkan kerugian bagi petani di Kabupaten Indramayu. Mengingat kekeringan merupakan kejadian yang dapat berulang, maka perlu dilakukan upaya pemantauan dan mengidentifikasi faktor-faktor bahaya kekeringan, agar dapat dikembangkan model bahaya kekeringan. Disamping itu, perlu dilakukan pemetaan untuk diketahui sebaran kekeringan sebagai salah satu pertimbangan dalam pengembangan pertanian dan kebijakan lainnya, serta dapat meminimalkan kerugian yang mungkin di alami di kemudian hari. Penelitian ini menggunakan metode dengan mengidentifikasi faktor-faktor bahaya kekeringan dan mengembangkan model kekeringan. Tiap-tiap faktor diberi skor dan bobot berdasarkan urutan kepentingan atau pengaruhnya terhadap bahaya kekeringan kemudian digabungkan dengan metode MCE (Multi Criteria Evaluation). Model diterapkan pada 3 (tiga) titik tahun yaitu 2003, 2008 dan 2012 dalam dua versi. Versi 1 yakni dengan tidak menyertakan jarak dari jaringan irigasi dan versi 2 adalah dengan menyertakan jarak dari jaringan irigasi. Hasil penelitian menunjukkan bahwa faktor bahaya kekeringan yang memiliki pengaruh paling besar sampai dengan paling rendah adalah curah hujan, penggunaan lahan, jarak ke sumber air, tekstur tanah, suhu permukaan tanah, sehingga diperoleh model dengan formulasi: $\mathrm{H}=(0.34 \mathrm{SPI})+(0.20 \mathrm{~L})+(0.19 \mathrm{~B})+(0.17 \mathrm{Jt})+(0.10 \mathrm{LST})$. Sebaran bahaya kekeringan pada model versi 2 memiliki luasan bahaya kekeringan lebih sedikit dari model versi 1 dan memiliki nilai akurasi lebih rendah dari versi 1 . Model versi 2 merupakan kondisi ideal, tetapi jaringan irigasi kurang berperan pada masa musim kemarau. Sementara itu, model versi 1 memiliki tingkat validasi yang cukup signifikan. Versi 1 merupakan kondisi yang mendekati keadaan sebenarnya di lapangan.

Kata kunci: Kekeringan, bahaya, suhu tanah, evaluasi multi kriteria, Indek Standar Curah Hujan

\section{PENDAHULUAN}

Kejadian bencana kekeringan di Indonesia selama tahun 2002-2009 menempati urutan kedua setelah banjir dengan rata-rata 156 kejadian per tahun (BNPB, 2009). Salah satu wilayah yang mengalami kekeringan adalah
Kabupaten Indramayu yang merupakan salah satu lumbung padi bagi Provinsi Jawa Barat dan nasional. Data Dinas pertanian Kabupaten Indramayu menunjukkan Kabupaten Indramayu mengalami puso/gagal panen dari tahun 2002-2009 rata-rata sebesar 12,787 hektar. Keadaan 
tersebut mengganggu kegiatan pertanian dan menyebabkan kerugian bagi petani.

Kekeringan pada dasarnya adalah keadaan kekurangan pasokan air pada suatu daerah untuk berbagai kegiatan, kelompok-kelompok dan sektor lingkungan dalam masa berkepanjangan, dapat mencapai beberapa bulan hingga tahunan (Wilhite dan Svoboda, 2000 dalam UNDP, 2011). Kejadian ini muncul bila suatu wilayah secara terus-menerus mengalami curah hujan di bawah rata-rata. Musim kemarau yang panjang akan menyebabkan kekeringan karena cadangan air tanah akan habis akibat penguapan, transpirasi, ataupun penggunaan lain oleh manusia. Situasi demikian dapat ditinjau secara klimatologi maupun hidrologis. Tinjauan secara klimatologis dapat dilakukan melalui penilaian terhadap Suhu Permukaan Tanah dan tinjauan secara hidrologis melalui penilaian Indeks Standar Curah Hujan. Nilai LST mampu mengidentifikasi permukaan yang relatif basah dan kering, sedangkan SPI dapat memantau pasokan air jangka pendek dan sumber daya air jangka panjang.

Wilhite (2000) berpendapat bahwa sebagai bencana alam, kekeringan berbeda dari bahaya alam lainnya. Perbedaan tersebut adalah 1) awal dan akhir kekeringan sulit ditentukan, dampak peningkatan kekeringan terjadi secara perlahan dan sering menumpuk melebihi periode waktu yang dipertimbangkan. Oleh karena itu, kekeringan sering disebut sebagai fenomena merayap; 2) kesulitan menetapkan batasan kekeringan yang menyebabkan kebingungan karena tidak memiliki definisi kekeringan yang universal/umum; 3) dampak kekeringan bersifat nonstruktural sehingga area menyebar lebih luas dibandingkan dengan kerusakan yang disebabkan oleh bahaya alam lainnya. Berbeda dengan kejadian-kejadian banjir, badai, gempa, dan tornado, kejadian kekeringan mempengaruhi badan air dari struktur sumber daya air dan jarang menyebabkan kerusakan pada bangunan badan air; 4) kegiatan manusia secara langsung dapat memicu memperburuk kekeringan, seperti pertanian intensif, irigasi berlebihan, penggundulan hutan, eksploitasi air tersedia secara berlebih, erosi yang berdampak negatif pada kemampuan tanah untuk menangkap dan menahan air.

ISDR (2009) menyatakan bahwa suatu rangkaian kejadian yang berpotensi menimbulkan kerusakan atau kerugian diartikan sebagai bahaya. Peristiwa kekeringan berpotensi menimbulkan kerusakan dan kerugian disebut bahaya kekeringan, apabila dibiarkan dapat menjadi bencana. Undang-undang Republik Indonesia No 24 Tahun 2007 tentang Penanggulangan Bencana menekankan bahwa pemantauan perlu dilakukan karena merupakan langkah antisipasi menghadapi suatu bencana, maka perlu dilakukan identifikasi faktor bahaya kekeringan dan dibuat peta bahaya kekeringan sebagai salah satu bahan pertimbangan dalam pengembangan pertanian dan kebijakan lainnya, serta dapat meminimalkan kerugian yang mungkin di alami dikemudian hari. Penelitian ini bertujuan: 1) mengidentifikasi faktor-faktor terkait bahaya kekeringan, 2) mengembangkan model bahaya kekeringan, 3) membuat Peta Bahaya Kekeringan, dan 4) menganalisis bahaya kekeringan di wilayah penelitian.

\section{BAHAN DAN METODE}

Penelitian dilakukan di Kabupaten Indramayu. Bahan yang digunakan adalah literatur dan hasil kajian berupa data dan peta tematik, citra satelit, kuesioner serta bahan lain yang menunjang penelitian. Alat yang digunakan berupa seperangkat komputer dengan perangkat lunak ArcGis 9.3, Idrisi, Microsoft Office, Global Positioning System (GPS) dan kamera dijital serta alat tulis.

Penelitian dilakukan 3 tahap yaitu 1) pengumpulan data, 2) pengolahan data, dan 3) analisis data. Masingmasing tahapan dapat diuraikan sebagai berikut;

\section{Pengumpulan Data}

Data yang digunakan (Tabel 1) terdiri dari data primer dan sekunder.

Tabel 1. Jenis dan sumber data yang digunakan dalam penelitian

\begin{tabular}{ll}
\hline \multicolumn{1}{c}{ Jenis Data } & \multicolumn{1}{c}{ Sumber Data } \\
\hline Peta Administrasi & Bappeda Kabupaten Indramayu \\
$\begin{array}{l}\text { Data Curah Hujan } \\
\text { bulanan }\end{array}$ & BMKG, PSDA Kabupaten Indramayu, BBWS \\
Citra Landsat tahun & $\begin{array}{l}\text { DAS Cimanuk - Cisanggarung } \\
\text { www.USGS.com }\end{array}$ \\
2003, 2008,2012 & \\
Penggunaan lahan & RBI skala 1:25,000, Citra Landsat \\
Peta Jenis Tanah & Peta Sumber Daya Tanah Tingkat Tinjau Skala \\
& 1: 250,000, BBSDLP tahun 2011 dan Peta \\
& Sistem Lahan Pulau Jawa (RePPProT) tahun \\
& 1989 skala 1: 250,000. \\
& RBI skala 1:25,000 dan hasil interpretasi citra, \\
Jaringan sungai dan & Peta Wilayah Pengairan Kabupaten Indramayu \\
sumber air & - dinas PSDA, Pertambangan dan Energi \\
& Kabupaten Indramayu \\
\hline
\end{tabular}

\section{Pengolahan Data}

Faktor-faktor Bahaya Kekeringan

\section{Indeks Standar Curah Hujan (Standardized Precipitation Index/SPI)}

Pengolahan SPI menggunakan data curah hujan bulanan 19 stasiun penakar hujan dari tahun 1996-2013 dengan menggunakan program SPI_sl_6.exe. Nilai SPI di joint table terhadap Peta lokasi stasiun penakar hujan dan diinterpolasi dengan metode IDW (Inverse Distance Weighted) untuk memperoleh Peta SPI. Nilai SPI dikelompokan berdasarkan pengelompokan oleh Mc Kee et al. (1993) dalam WMO (2012) (Tabel 2).

Tabel 2. Kelas indeks standar presipitasi (SPI)

\begin{tabular}{cccc}
\hline No & Nilai & Kategori & Kelas \\
\hline 1 & $\geq 2.00$ & Ekstrim Basah & 1 \\
2 & $1.5-1.99$ & Sangat Basah & 2 \\
3 & $1-1.4$ & Basah Sedang & 3 \\
4 & $-0.99-0, .9$ & Normal & 4 \\
5 & $-1.49--1.00$ & Kering Sedang & 5 \\
6 & $-1.99--1.5$ & Sangat Kering & 6 \\
7 & $\leq-2.00$ & Ekstrim Kering & 7 \\
\hline
\end{tabular}




\section{Temperatur Permukaan Tanah (Land Surface Temperature/LST)}

Penghitungan nilai LST dilakukan pada band 6 citra Landsat. Band 6 memiliki panjang gelombang $10.4 \mu$ hingga $12.5 \mu$ sehingga mampu untuk membedakan panas dan kelembaban tanah. Tahapan penghitungan dilakukan sebagai berikut:

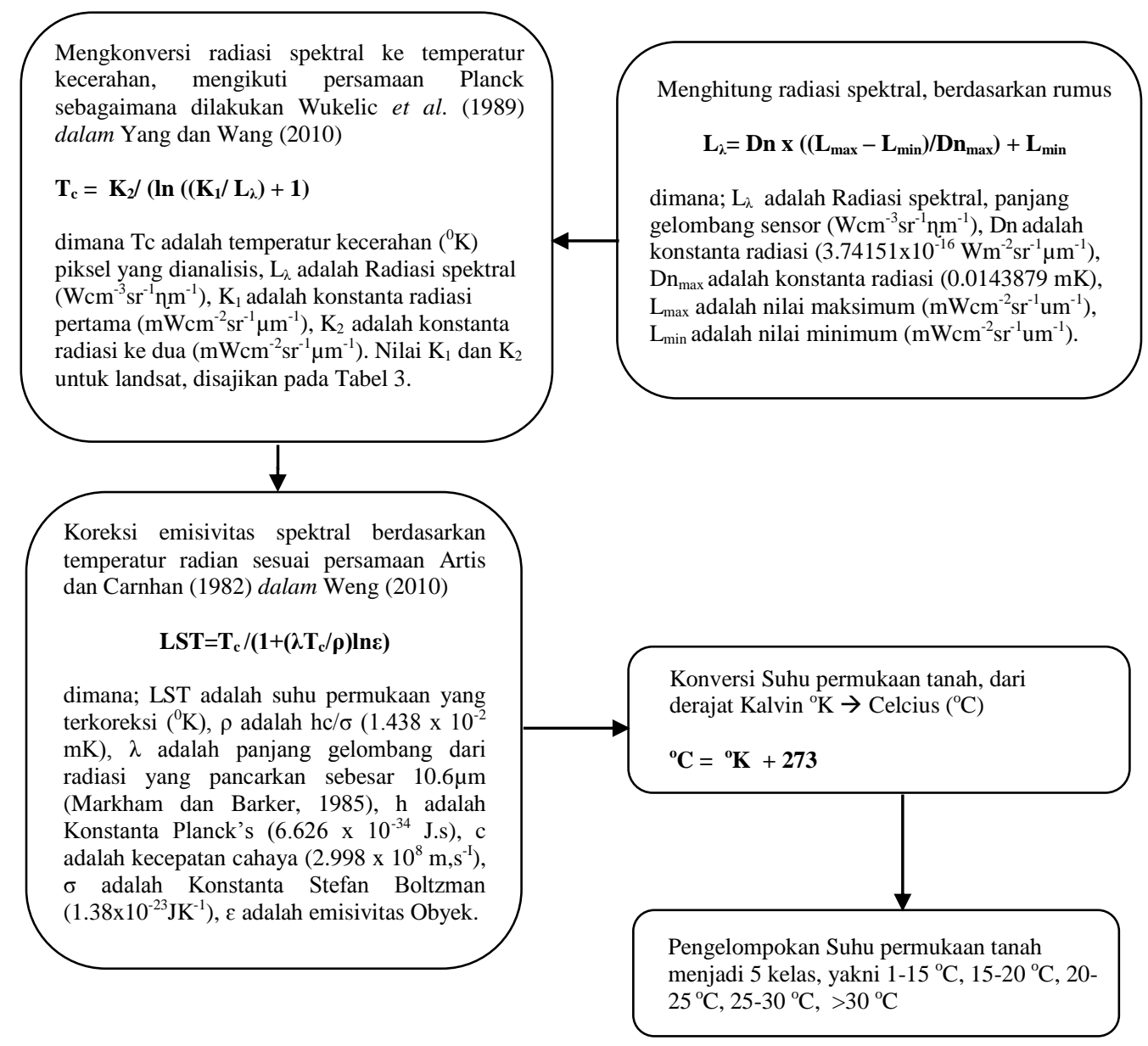

Gambar 1. Alur kegiatan pengolahan temperatur permukaan tanah

Tabel 3. Konstanta radiasi untuk Landsat

\begin{tabular}{lcc}
\hline \multicolumn{1}{c}{ Citra Satelit } & K1 & K2 \\
\hline Landsat5 TM Band6 & 607.76 & 1260.56 \\
Landsat7 ETM+ Band6 & 666.09 & 1282.71 \\
Landsat 8 Band 11 & 480.89 & 1201.14 \\
\hline
\end{tabular}

\section{Kelas Tekstur Tanah}

Kelas tekstur tanah didasarkan pada jenis tanah dan dipadupadankan dengan sistem lahan dikarenakan dalam penelitian ini tidak dilakukan uji tanah.

Tekstur tanah memiliki keterkaitan dalam hal kapasitas memegang air yang mempengaruhi ketersediaan air dalam tanah. Pengelompokan tekstur tanah (Tabel 4) didasarkan pada klasifikasi tekstur tanah untuk penilaian kemampuan lahan menurut Arsyad (2006).

Tabel 4. Kelas tekstur tanah di Indramayu

\begin{tabular}{lllc}
\hline & Kelompok Tekstur & \multicolumn{1}{c}{ Kelompok } \\
\hline t1 & Bertekstur halus & Liat berpasir, liat berdebu dan liat & 1 \\
t2 & Bertekstur agak halus & Lempung liat berpasir, lempung berliat dan lempung liat berdebu & 2 \\
t3 & Bertekstur sedang & Lempung, Lempung berdebu dan debu & 3 \\
t4 & Bertekstur agak kasar & Lempung berpasir, lempung berpasir halus dan lempung berpasir sangat halus & 4 \\
t5 & Bertekstur kasar & Pasir berlempung dan pasir & 5 \\
\hline
\end{tabular}




\section{Buffering Jaringan Sungai dan Sumber Air Lainnya}

Pada umumnya, jarak 100 meter dari sumber air merupakan zona aman dari kekurangan air karena masih mudah mendapatkan air. Untuk itu Buffer dilakukan dengan batasan 0-100 m, 100-200 m, 200-300 m, 300-400 $\mathrm{m}, 400-500 \mathrm{~m}$ dan $>500 \mathrm{~m}$.

\section{Jenis Penggunaan Lahan}

Jenis penggunaan lahan dari hasil interpretasi citra landsat dikelompokan ke dalam 4 kelas, yakni; 1) rawa, tubuh air (sungai, danau, pantai/laut), 2) hutan, mangrove, perkebunan, kebun campuran, 3) tegalan, sawah, semak, tambak, 4) lahan terbangun, lahan terbuka. Pantai/laut turut didelineasi dikarenakan berada dalam batas wilayah.

\section{Pengembangan Model Bahaya Kekeringan dan Pemetaan Bahaya Kekeringan}

Parameter indeks bahaya kekeringan disusun dari faktor-faktor bahaya kekeringan. Parameter disusun berdasarkan urutan kepentingannya mulai dari parameter paling berpengaruh hingga kurang berpengaruh. Urutan kepentingan dilakukan dengan penyebaran kuesioner sebanyak 30 responden.

Parameter tersusun diberikan pembobotan secara bertingkat dari 1 sampai 9. Parameter paling penting diberikan bobot paling besar dan parameter kurang penting diberikan bobot paling kecil. Selanjutnya dinormalisasi sehingga memiliki standar yang sama. Hasil perhitungan digunakan untuk menentukan nilai konstanta pada persamaan indeks bahaya kekeringan, yakni: $\mathrm{H}=(\mathrm{c} 1 \mathrm{SPI})+(\mathrm{c} 2 \mathrm{~L})+(\mathrm{c} 3 \mathrm{~B})+(\mathrm{c} 4 \mathrm{Jt})+(\mathrm{c} 5 \mathrm{LST})$, dimana: $\mathrm{H}$ adalah indeks bahaya kekeringan, SPI adalah skor standar presipitasi indeks, L adalah skor penggunaan lahan, B adalah skor buffer dari sumber air, Jt adalah skor tekstur tanah, LST adalah suhu permukaan tanah, c1-c5 adalah konstanta. Model diterapkan pada tiga titik tahun skala 5 tahunan yaitu 2003, 2008 dan 2012 dalam dua versi. Versi 1 yakni tidak menyertakan jarak dari jaringan irigasi dan versi 2 adalah menyertakan jarak dari jaringan irigasi. Pembuatan peta bahaya kekeringan dilakukan menggunakan metode Multi-Criteria Evaluation/MCE. Alur kegiatan disajikan pada Gambar 1.

\section{Validasi Model}

Model divalidasi terhadap data kekeringan dari Dinas Pertanian dan Peternakan Kabupaten Indramayu dan informasi dari petani, masyarakat dan pemerintah.

\section{Analisis Data}

\section{Pemetaan Bahaya Kekeringan}

Pemetaan bahaya kekeringan disusun berdasarkan hasil penghitungan model baik versi 1 maupun versi 2 . Peta-peta disusun menjadi 3 kelas yakni kelas bahaya tinggi, sedang dan rendah dengan menggunakan metode natural break yang dimodifikasi.

\section{Analisis Bahaya Kekeringan}

Analisis model bahaya kekeringan versi 1 dan versi 2 dilakukan dengan melihat sebaran dan tinjauan hasil validasi masing-masing model.

\section{HASIL DAN PEMBAHASAN}

\section{Faktor Bahaya Kekeringan dan Pembobotan}

Faktor-faktor bahaya kekeringan di wilayah penelitian dipengaruhi oleh faktor iklim, hidrologi dan manusia. Faktor iklim, dalam hal ini adalah curah hujan dan suhu permukaan tanah, dan faktor hidrologi yakni jarak ke sumber air dan tekstur tanah, serta faktor manusia yaitu jenis penggunaan lahan. Berdasarkan hasil kuesioner (Tabel 5), 26 responden memilih curah hujan sebagai urutan kepentingan pertama (ke 1) dan tidak ada yang memilih faktor suhu permukaan tanah sebagai urutan pertama namun sebagian besar memilih untuk urutan ke 5 . Demikian pula faktor jenis tanah, sebagian besar memilih sebagai urutan ke 4 dan faktor penggunaan lahan untuk urutan ke 2 dan ke 3 . Urutan kepentingan faktor bahaya kekeringan secara berurutan adalah: curah hujan, jenis penggunaan lahan, jarak ke sumber air, tekstur tanah, dan suhu permukaan tanah.

Tabel 5. Urutan kepentingan faktor bahaya kekeringan

\begin{tabular}{lcccccc}
\hline \multirow{2}{*}{ Faktor Kekeringan } & \multicolumn{5}{c}{ Urutan kepentingan } & \multirow{2}{*}{ Jumlah } \\
\cline { 2 - 6 } & 1 & 2 & 3 & 4 & 5 & \\
\hline Curah hujan & 26 & 1 & 2 & 0 & 1 & 30 \\
Penggunaan lahan & 1 & 11 & 10 & 3 & 5 & 30 \\
Jarak ke sumber air & 1 & 11 & 6 & 8 & 4 & 30 \\
Jenis tanah & 2 & 5 & 6 & 14 & 3 & 30 \\
Suhu permukaan tanah & 0 & 3 & 5 & 5 & 17 & 30 \\
\hline
\end{tabular}

\section{Pemetaan Faktor-faktor Bahaya Kekeringan}

\section{Indeks Standar Curah Hujan}

Rata-rata curah hujan tahunan dari tahun 19962013 (Gambar 2) berkisar 1,088-1,966.4 mm. Rata-rata curah hujan tahunan paling rendah terjadi tahun 2003 dan tahun 2012 dan paling tinggi terjadi tahun 1998 dan 2010. Akan tetapi, curah hujan terendah sebesar $405 \mathrm{~mm}$ terjadi tahun 2009 dan tertinggi sebesar 2,630 mm terjadi tahun 2010.

Indeks Standar Curah Hujan (SPI) hasil pengolahan menunjukkan bahwa nilai SPI masa musim kemarau (MeiOktober) skala waktu 12 bulanan berkisar -2.70-2.57 dimana nilai maksimum terjadi tahun 2002 dan nilai minimun terjadi tahun 2009. Hal ini menunjukkan bahwa wilayah penelitian sering mengalami kekeringan dengan kondisi ekstrim kering, yakni terjadi pada tahun 2001, 2003, 2005, 2006, 2009 dan 2012 dan terjadi kondisi sangat kering yakni pada tahun 1998, 2002, 2007 dan 2010 .

Kondisi masa musim kemarau di seluruh stasiun (Gambar 3a) menggambarkan bentuk grafik menghadap ke atas (positif) menunjukkan kondisi basah sedangkan bentuk grafik menghadap ke bawah (negatif) menunjukkan kondisi kering. Pada gambar tersebut terlihat bahwa pada masa musim kemarau, tidak semua grafik menunjukkan bentuk grafik yang menghadap ke bawah (negatif). Masa musim kemarau tahun 1999, 2002 dan 2008, bentuk grafik hampir seluruhnya menghadap ke arah atas (positif/kondisi basah), sedangkan tahun 2003, 2005 dan 2012 bentuk grafik hampir seluruhnya menghadap ke arah bawah (negatif/kondisi kering). 
Gambar 3b menyajikan sebaran kondisi masa musim kemarau hasil interpolasi nilai SPI. Kondisi basah pada musim kemarau tahun 1999, terjadi di sebagian kecil wilayah penelitian. Tahun 2008, terjadi seimbang antara area yang tergolong basah sedang dan normal. Sementara, tahun 2002 bervariasi antara kondisi normal hingga ekstrim basah. Demikian pula tahun 2012, kondisi kering sedang hingga ekstrim kering tersebar di sebagian kecil wilayah. Akan tetapi pada tahun 2003 dan 2005, sebagian besar wilayah berada pada kondisi kering sedang hingga sangat kering. Wilayah yang tergolong ekstrim kering hanya sedikit. Hal ini dapat disebabkan karena adanya pengaruh El nino yang terjadi pada tahun 2003 dan 2005 (BMKG, 2010). Pada tahun-tahun yang lainnya terlihat bahwa masa musim kemarau berada pada kondisi normal.

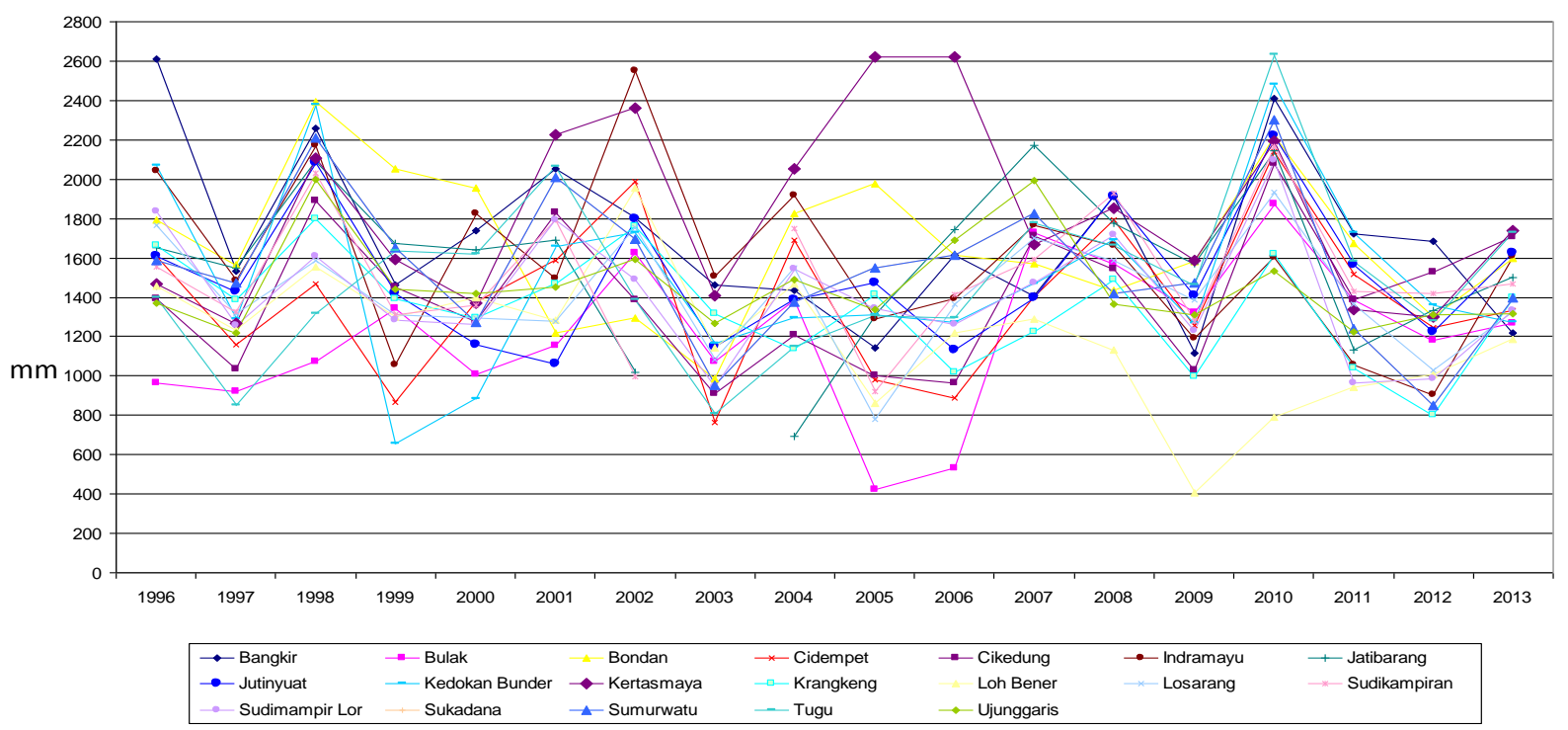

Gambar 2. Curah hujan tahunan di tiap stasiun tahun 1996-2013
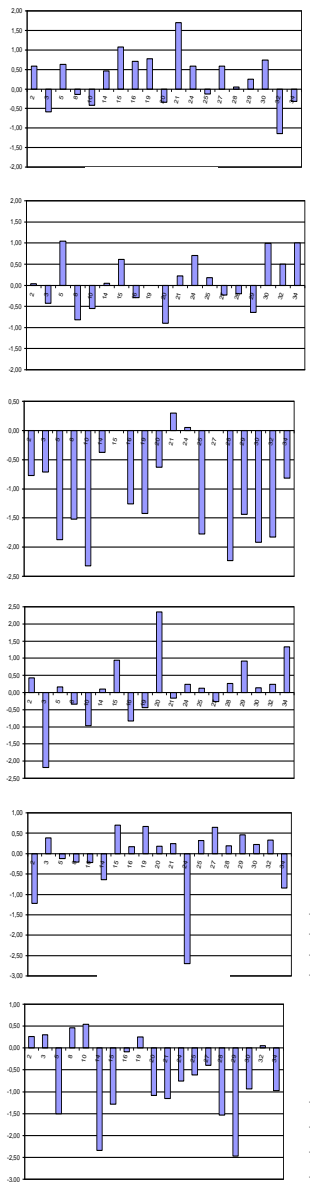
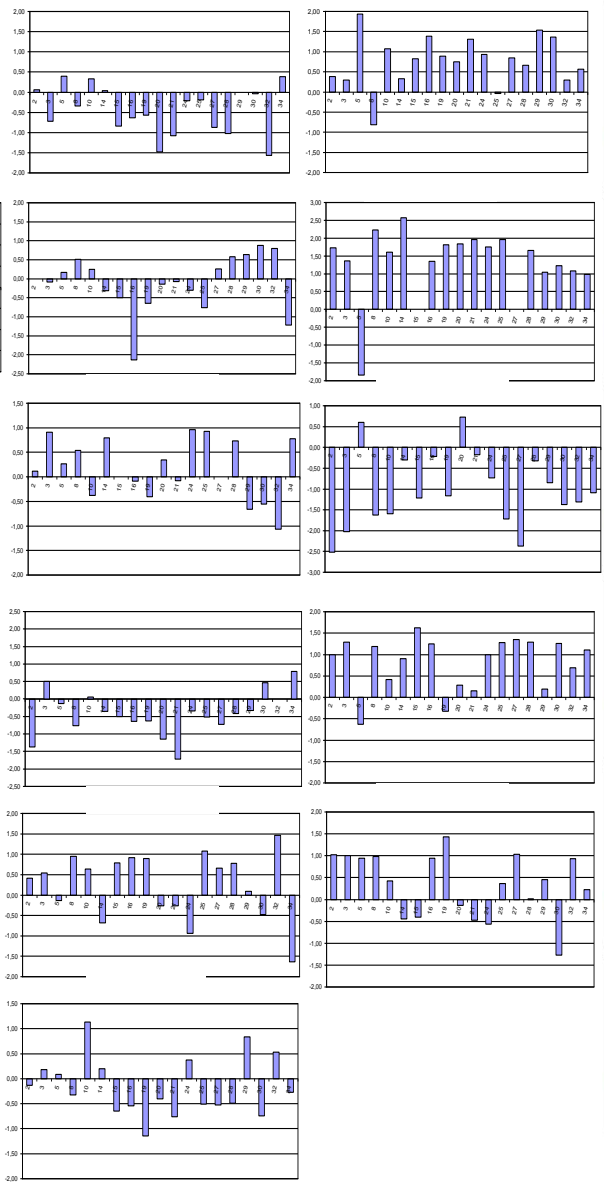
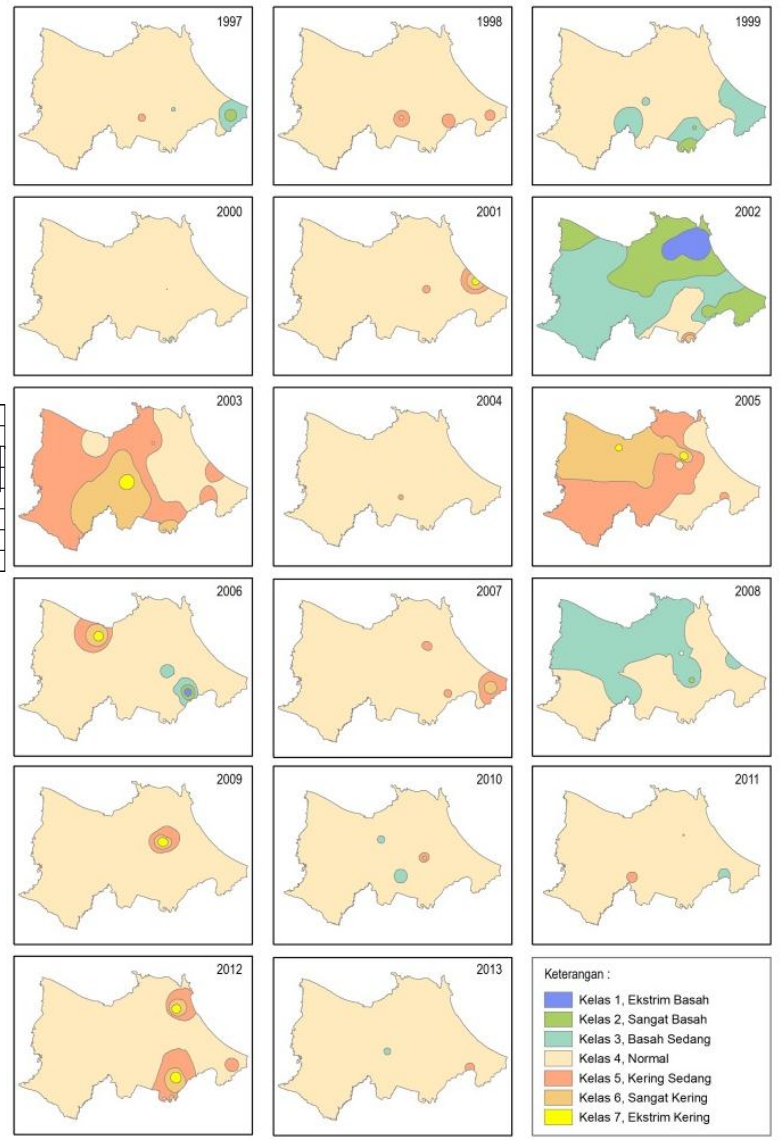

Gambar 3. Rataan nilai SPI 12 bulanan masa kemarau di tiap stasiun (a) dan pola nilai SPI 12 bulanan pada masa kemarau (b) 


\section{Penggunaan Lahan}

Jenis penggunaan lahan pada tahun 2003, 2008 maupun 2012 adalah hutan, sawah, mangrove, perkebunan kebun campuran, tegalan, pemukiman, industri, semak, tambak, lahan terbuka, sungai/tubuh air, rawa dan pantai/laut. Tahun 2008 dan 2012 terdapat jenis penggunaan lahan baru yakni jalan tol. Jenis penggunaan lahan yang dominan (lebih dari 60\%) adalah sawah. Oleh karena itu wilayah tersebut sangat membutuhkan air dan sistem pengairan yang memadai agar pertumbuhan tanaman tidak terganggu.

\section{Jaringan Sumberdaya Air}

Wilayah Kabupaten Indramayu berada dalam pengawasan Balai Besar Wilayah Sungai CimanukCisanggarung. Daerah aliran sungai (DAS) di wilayah ini yakni DAS Cimanuk, DAS Ciwarigin, DAS Cimanggis, DAS Cipanas, DAS Kali Beji dan DAS Cipunagara. Dengan demikian wilayah ini memiliki sumber air dari sungai. Disamping itu, memiliki danau/waduk dan embung diantaranya Waduk Cipancuh yang merupakan salah satu sumber air utama yang di kelola oleh PT Jasa Tirta II untuk disebarkan ke berbagai tempat sesuai kebutuhan selain untuk irigasi.

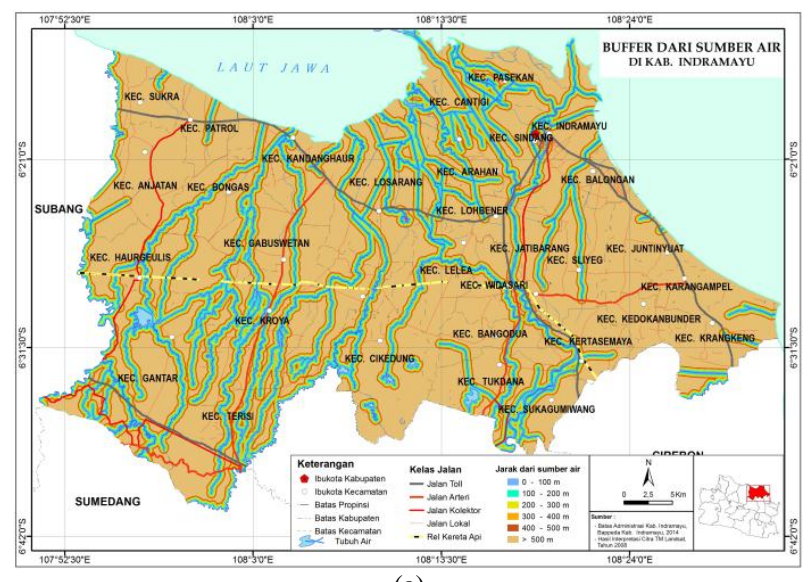

(a)

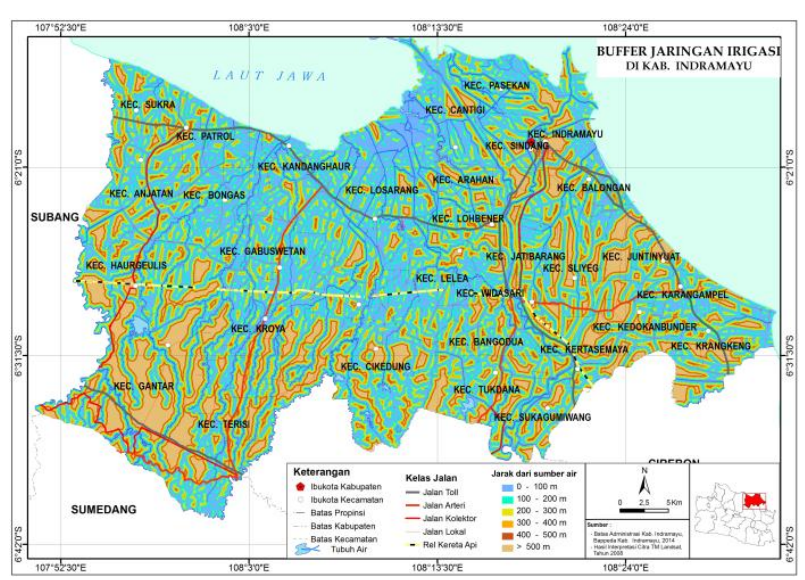

(b)

Gambar 4. Buffer dari sungai dan danau/waduk (a) dan buffer dari jaringan irigasi (b)

Buffer dari sungai dan danau/waduk serta jaringan irigasi disajikan pada Gambar 4. Gambar 4 (b), menunjukkan sebagian besar area terlintasi oleh jaringan irigasi pada jarak kurang dari 500 meter. Area yang belum terlintasi oleh jaringan irigasi yakni sebagian besar wilayah Gantar dan Terisi merupakan daerah tadah hujan.

\section{Tekstur Tanah}

Sebaran kelas tekstur tanah menunjukkan bahwa wilayah penelitian didominasi jenis tanah bertekstur agak halus, yakni mencapai sekitar 63.7\%. Tekstur tanah lainnya adalah tanah tekstur halus mencakup luasan sekitar $24.8 \%$ dan area yang bertekstur sedang dan agak kasar masing-masing seluas $19.4 \%$ dan $2.2 \%$.

\section{Suhu Permukaan Tanah}

Hasil pengolahan citra landsat pada Gambar 5 dan Tabel 6 menunjukkan bahwa pada tahun 2003 bulan Mei yang merupakan awal musim kemarau memiliki suhu permukaan tanah $15.3^{\circ} \mathrm{C}-34^{\circ} \mathrm{C}$ dan pada bulan Agustus yakni memiliki suhu $-12.8^{0} \mathrm{C}-31.2^{\circ} \mathrm{C}$. Demikian pula pada citra landsat tahun 2008, suhu pada bulan Mei memilki kisaran $10.5^{\circ} \mathrm{C}-33.5^{\circ} \mathrm{C}$ dan bulan Oktober antara $13.5^{\circ} \mathrm{C}$ $32.7^{\circ} \mathrm{C}$. Sementara, pada citra landsat bulan Oktober tahun 2012 adalah $14.5^{\circ} \mathrm{C}-40.8^{\circ} \mathrm{C}$.

Tahun 2003 pada bulan Mei, pada umumnya sebagian besar wilayah berada pada kelas 3 dan 4 yakni pada rentang suhu $21^{\circ} \mathrm{C}-30^{\circ} \mathrm{C}$. Suhu kelas 4 meliputi luas wilayah sekitar $65 \%$ dan kelas 3 meliputi $34.6 \%$. Kondisi ini berbeda dengan bulan Agustus pada tahun yang sama dimana kondisi suhu permukan tanah lebih terlihat merata pada berbagai kelas, yakni kelas 1 meliputi $15.45 \%$, kelas 2 meliputi $21.62 \%$ dan kelas 3 meliputi $28.18 \%$. Kondisi pada tahun 2003 ini, memperlihatkan bahwa kekeringan telah terjadi pada bulan Mei yang merupakan awal musim kemarau dan kondisi tersebut menurun pada bulan Agustus yang merupakan masa menjelang akhir musim kemarau.

Kondisi tahun 2008, pada bulan Mei didominasi oleh tingkat suhu permukaan tanah kelas $3\left(21^{\circ} \mathrm{C}-25^{\circ} \mathrm{C}\right)$ yakni seluas $69.07 \%$ dan kelas $1\left(<15^{\circ} \mathrm{C}\right)$ yakni meliputi $21.27 \%$. Pada bulan Oktober, areal yang tergolong kelas 3 sekitar $27.53 \%$ dan terdapat areal yang tergolong kelas 4 sebanyak $49.50 \%$. Kondisi ini menunjukkan adanya peningkatan areal yang mengalami kekeringan dengan suhu permukaan tanah lebih panas. Namun kondisi lebih ekstrim diperlihatkan pada Oktober tahun 2012 dimana sebagian besar wilayah berada pada kelas 4 dan 5 yakni suhu $26^{\circ} \mathrm{C}-30^{\circ} \mathrm{C}$, hingga lebih tinggi dari $30^{\circ} \mathrm{C}$. Suhu kelas 5 meliputi luas sekitar $73.6 \%$ dan kelas 4 meliputi $21.7 \%$.

\section{Pengembangan Model Bahaya Kekeringan}

Hasil pembobotan dan normalisasi dari Tabel 5 disajikan pada Tabel 7 menunjukkan bahwa faktor bahaya kekeringan urutan pertama adalah curah hujan, memiliki skor 252 dengan nilai rata-rata 0.34 . Nilai tersebut adalah nilai tertinggi, sedangkan skor paling rendah yaitu 78 dengan nilai rata-rata 0.10 dimiliki oleh suhu permukaan tanah yang merupakan faktor paling kecil. Model indeks bahaya kekeringan yang dihasilkan yakni: $\mathrm{H}=(0.34 \mathrm{SPI})+(0.20 \mathrm{~L})+(0.19 \mathrm{~B})+(0.17 \mathrm{Jt})+(0.10 \mathrm{LST})$. Skor indeks bahaya kekeringan yang dihasilkan berkisar dari 0.06 sampai 0.3. Indeks bahaya kekeringan dikelompokan menjadi 4 kelas, sebagaimana disajikan pada Tabel 8. 


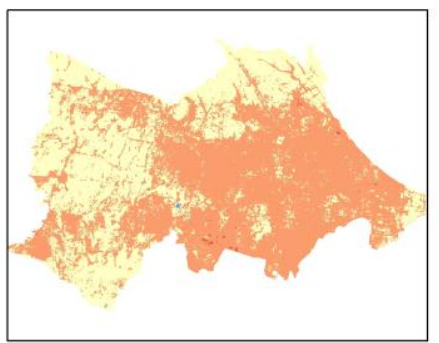

Kondisi Suhu Permukaan Tanah Bulan Mei Tahun 2003

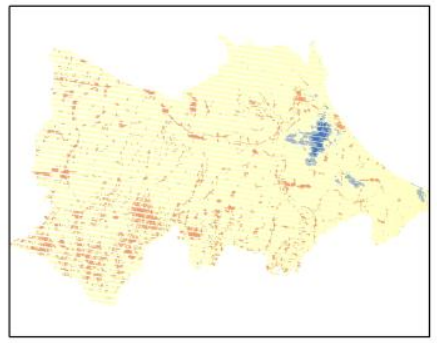

Kondisi Suhu Permukaan Tanah Bulan Mei Tahun 2008

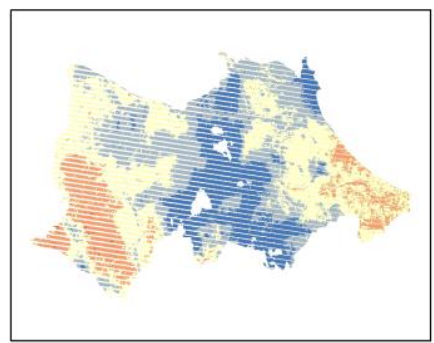

Kondisi Suhu Permukaan Tanah Bulan Agustus Tahun 2003

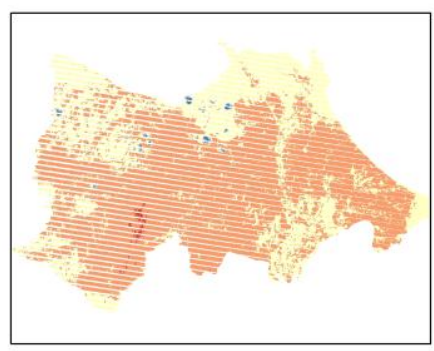

Kondisi Suhu Permukaan Tanah Bulan Oktober Tahun 2008

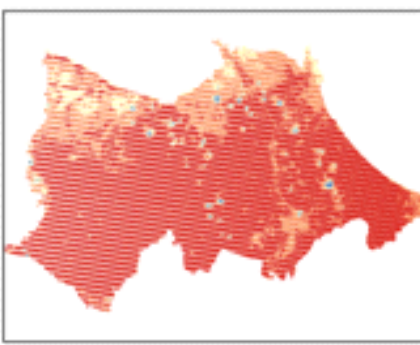

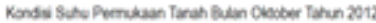

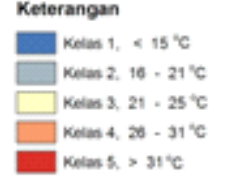

Gambar 5. Sebaran suhu permukaan tanah pada berbagai kondisi

Tabel 6. Luasan suhu permukaan tanah tahun 2003, 2008 dan 2012

\begin{tabular}{ccccccc}
\hline \multirow{2}{*}{ Kelas } & \multirow{2}{*}{ Suhu } & Mei-03 & Agust-03 & Mei-08 & Okt-08 & Okt-12 \\
\cline { 3 - 7 } & & 44,583 & 52,119 & 44,583 & 46,341 & 48,752 \\
\hline 0 & $<15{ }^{\circ} \mathrm{C}$ & 780 & 32,349 & 780 & 297 & 207 \\
1 & $16-20{ }^{\circ} \mathrm{C}$ & 2,508 & 45,263 & 2,508 & 998 & 1,160 \\
2 & $21-25{ }^{\circ} \mathrm{C}$ & 144,650 & 58,986 & 144,650 & 57,597 & 6,156 \\
3 & $26-30^{\circ} \mathrm{C}$ & 16,948 & 20,604 & 16,948 & 103,744 & 34,906 \\
4 & 1 & 148 & 1 & 492 & 118,289 \\
5 & $>31^{\circ} \mathrm{C}$ & 209,470 & 209,470 & 209,470 & 209,470 & 209,470 \\
\hline
\end{tabular}

Tabel 7. Hasil normalisasi faktor bahaya kekeringan

\begin{tabular}{lcccccccc}
\hline \multicolumn{1}{c}{ Urutan Kepentingan } & 1 & 2 & 3 & 4 & 5 & \multicolumn{2}{c}{ Jumlah } \\
\multicolumn{1}{c}{ Bobot Nilai } & 9 & 7 & 5 & 3 & 1 & Skor & Persentase \\
\hline Curah hujan & 234 & 7 & 10 & 0 & 1 & 252 & 0.34 \\
Penggunaan lahan & 9 & 77 & 50 & 9 & 5 & 150 & 0.20 \\
Jarak ke sumber air & 9 & 77 & 30 & 24 & 4 & 144 & 0.19 \\
Jenis tanah & 18 & 35 & 30 & 42 & 3 & 128 & 0.17 \\
Suhu permukaan tanah & 0 & 21 & 25 & 15 & 17 & 78 & 0.10 \\
\hline
\end{tabular}

Tabel 8. Kelas indeks bahaya kekeringan

\begin{tabular}{lll}
\hline Kelas & \multicolumn{1}{c}{ Skor } & \multicolumn{1}{c}{ Kelas Bahaya Kekeringan } \\
\hline 1 & $\leq 0.1$ & Tidak bahaya kekeringan \\
2 & $0.1-0.2$ & Bahaya kekeringan rendah \\
3 & $0.2-0.235$ & Bahaya kekeringan sedang \\
4 & $\geq 0.235$ & Bahaya kekeringan tinggi \\
\hline
\end{tabular}

\section{Pemetaan dan Analisis Bahaya Kekeringan}

Kelas bahaya kekeringan versi 1 (Tabel 9 dan Gambar 6a) dan versi 2 (Tabel 10 dan Gambar 6b), menunjukkan bahwa pada tahun 2003 memiliki luas lahan yang tergolong bahaya tinggi paling luas dibandingkan tahun 2008 dan 2012. Hal ini terkait dengan terjadinya kemarau panjang pada tahun 2003 sehingga nilai SPI mencapai kelas ekstrim kering. Pada model versi 1, kelas bahaya tinggi pada tahun 2003 di awal musim kemarau mencapai luasan sekitar $21.2 \%$ dan menjelang akhir mu sim kemarau mencapai sekitar 8.9\%. Pada tahun 2008, kondisi awal musim kemarau dan menjelang akhir musim kemarau memiliki luasan masing-masing sekitar $1.8 \%$ dan 3.1\%. Namun, pada tahun 2012 area yang berada pada kondisi bahaya tinggi mencapai $11.6 \%$. Kondisi ini lebih luas daripada tahun 2008. Sementara itu, model versi 2 menunjukkan sebagian besar kondisi lahan pada awal musim kemarau maupun akhir musim kemarau berada pada kondisi yang tergolong kelas bahaya rendah. Luas area yang berada pada kondisi bahaya tinggi rata-rata kurang dari $3 \%$ pada semua tahun.

Pada model versi 2 jumlah area yang mengalami kondisi bahaya tinggi lebih sedikit daripada model versi 1. Berkurangnya lahan-lahan yang berstatus bahaya tinggi dapat terjadi karena adanya peranan dari jaringan irigasi. 


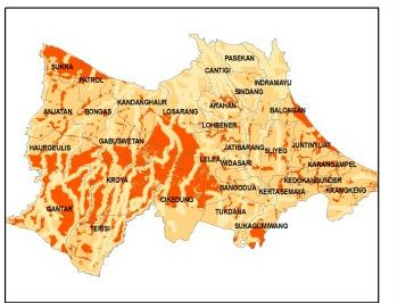

Mei - Tahun 2003

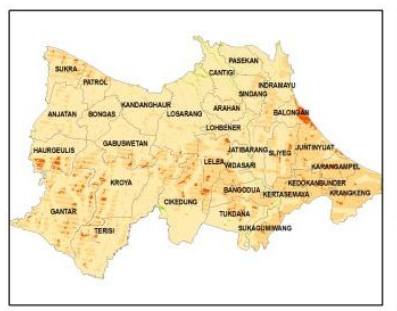

Mei - Tahun 2008

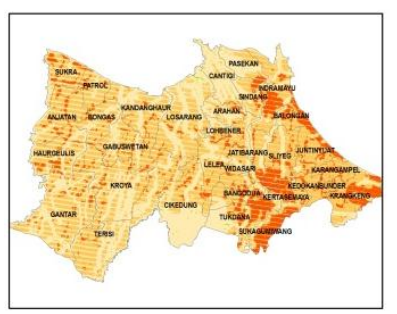

Oktober - Tahun 2012

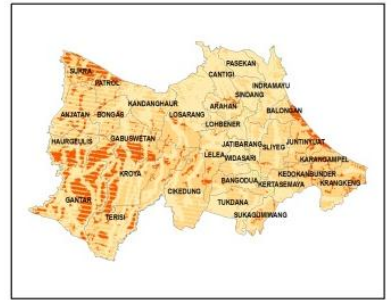

Agustus - Tahun 2003

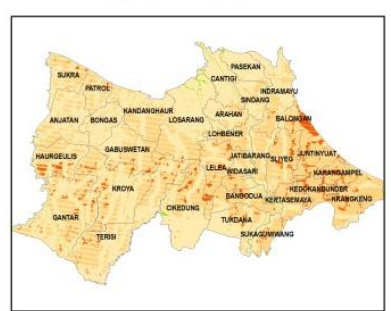

Oktober - Tahun 2008

\section{Keterangan}

- Tidak Bahaya

Bahaya Rendah

Bahaya Sedang
Bahaya Tinggi

(a)

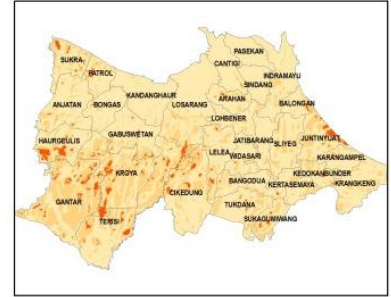

Mei - Tahun 2003

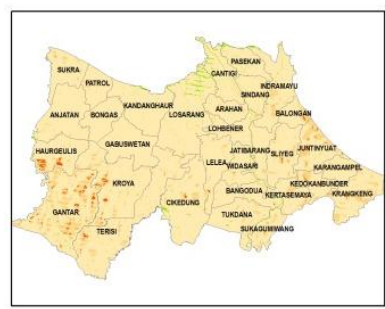

Mei - Tahun 2008

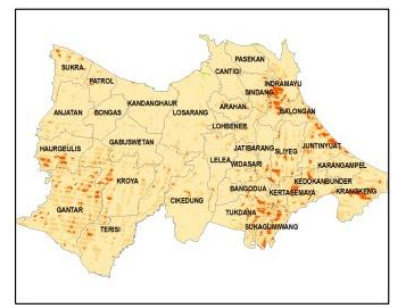

Oktober - Tahun 2012

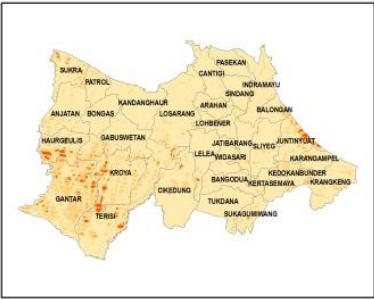

Agustus - Tahun 2003

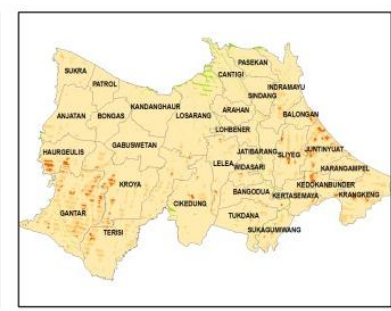

Oktober - Tahun 2008

Keterangan

Tidak Bahaya

Bahaya Rendah

Bahaya Sedang
Bahaya Tinggi

Gambar 6. Sebaran bahaya kekeringan versi 1 (a) dan sebaran bahaya kekeringan versi 2 (b)

Tabel 9. Kelas lahan berdasarkan model versi 1

\begin{tabular}{cccccc}
\hline Kelas Bahaya & Mei-03 & Mei-08 & Agust-03 & Okt-08 & Okt-12 \\
\hline Bahaya Tinggi & 44,484 & 3,859 & 18,567 & 6,552 & 24,194 \\
Bahaya Sedang & 56,978 & 143,859 & 99,082 & 120,840 & 92,649 \\
Bahaya Ringan & 107,861 & 59,840 & 91,137 & 80,251 & 92,062 \\
Tidak Bahaya & 142 & 1,908 & 680 & 1,821 & 561 \\
\hline Jumlah & 209,466 & 209,466 & 209,466 & 209,464 & 209,466 \\
\hline
\end{tabular}

Tabel 10. Kelas lahan berdasarkan model versi 2

\begin{tabular}{cccccc}
\hline Kelas Bahaya & Mei-03 & Mei-08 & Agust-03 & Okt-08 & Okt-12 \\
\hline Bahaya Tinggi & 5,066 & 1,162 & 2,603 & 1,717 & 5,768 \\
Bahaya Sedang & 55,937 & 16,861 & 31,458 & 22,277 & 39,013 \\
Bahaya Ringan & 148,320 & 189,006 & 174,712 & 183,133 & 164,065 \\
Tidak Bahaya & 143 & 2,436 & 692 & 2,337 & 619 \\
\hline Jumlah & 209,466 & 209,466 & 209,466 & 209,464 & 209,466 \\
\hline
\end{tabular}

Pada umumnya, areal-areal di sekitar sepanjang aliran sungai atau danau berada pada kondisi Bahaya Rendah karena aliran sungai masih memiliki cukup air untuk mengairi sawah di sekitar aliran sungai saja. Selisih area yang mengalami penurunan status terlihat cukup nyata. Namun penelitian ini tidak memperhitungkan ketersediaan air dalam jaringan irigasi sehingga masih terdapat kekurangan mengenai keterkaitan jaringan irigasi dengan luas lahan yang terkena bahaya. Jaringan irigasi yang terdapat di lokasi penelitian, banyak yang mengalami kekosongan air karena kurangnya pasokan air dari saluran induk sehingga turut mengalami kekeringan.

\section{Validasi Model Bahaya Kekeringan}

Model bahaya kekeringan yang divalidasi dengan data kekeringan dari Dinas Pertanian dan Peternakan Kabupaten Indramayu, ditunjukkan pada Tabel 11 dan Tabel 12. Tabel 11, memperlihatkan bahwa tingkat keakuratan yang cukup tinggi adalah pada awal musim kemarau 2003 yakni mencapai $80.49 \%$ dan pada akhir musim kemarau 2012 mencapai 66.19\%. Pada 2008 baik awal musim kemarau maupun akhir musim kemarau memiliki tingkat keakuratan lebih kecil dibandingkan tahun 2003 dan 2012. 
Tabel 11. Validasi model versi 1 pada lahan pertanian dengan data puso

\begin{tabular}{|c|c|c|c|c|c|}
\hline \multirow{2}{*}{ Tahun } & \multicolumn{2}{|c|}{$\begin{array}{c}\text { Hasil Model Versi } 1 \text { pada Kelas Bahaya } \\
\text { Tinggi (ha) } \\
\end{array}$} & \multirow{2}{*}{$\begin{array}{l}\text { Luas Lahan Puso } \\
\text { (ha) }\end{array}$} & \multicolumn{2}{|c|}{ Persentase (\%) } \\
\hline & Awal kemarau & Akhir Kemarau & & $\begin{array}{c}\text { Awal } \\
\text { kemarau }\end{array}$ & $\begin{array}{c}\text { Akhir } \\
\text { Kemarau }\end{array}$ \\
\hline 2003 & 27,756 & 8,861 & 34,482 & 80.49 & 25.70 \\
\hline 2008 & 0 & 181 & 28,425 & - & 0.64 \\
\hline 2012 & - & 8,719 & 13,173 & - & 66.19 \\
\hline
\end{tabular}

Tabel 12. Validasi model versi 2 pada lahan pertanian dengan data puso

\begin{tabular}{|c|c|c|c|c|c|}
\hline \multirow{2}{*}{ Tahun } & \multicolumn{2}{|c|}{$\begin{array}{c}\text { Hasil Model Versi } 2 \text { pada Kelas Bahaya } \\
\text { Tinggi (ha) }\end{array}$} & \multirow{2}{*}{$\begin{array}{l}\text { Luas Lahan Puso } \\
\text { (ha) }\end{array}$} & \multicolumn{2}{|c|}{ Persentase $(\%)$} \\
\hline & Awal kemarau & Akhir Kemarau & & $\begin{array}{c}\text { Awal } \\
\text { kemarau }\end{array}$ & $\begin{array}{c}\text { Akhir } \\
\text { Kemarau }\end{array}$ \\
\hline 2003 & 1,107 & 712 & 34,482 & 3.21 & 2.07 \\
\hline 2008 & - & 82 & 28,425 & - & 0.29 \\
\hline 2012 & & 1,864 & 13,173 & & 14.15 \\
\hline
\end{tabular}

Sementara itu, Tabel 12 memperlihatkan bahwa pada awal musim kemarau maupun akhir musim kemarau untuk masing-masing tahun memiliki tingkat keakuratan kurang dari $15 \%$ dimana tahun 2008 memiliki tingkat akurasi paling rendah. Validasi model versi 2 memiliki tingkat keakuratan lebih rendah dari model versi 1.

Meskipun model versi 2 memiliki nilai akurasi lebih rendah dari versi 1 , model versi 2 merupakan kondisi ideal dimana keberadaan jaringan irigasi dimaksudkan untuk memenuhi kebutuhan air lahan sawah agar terhindar dari kekeringan dan tanaman dapat berproduksi dengan baik serta tidak terjadi gagal panen. Pada kenyataannya, jaringan irigasi kurang berperan pada masa musim kemarau. Sementara itu, model versi 1 memiliki tingkat validasi yang cukup signifikan terutama pada tahun 2003 dan 2012. Hal ini menunjukkan bahwa versi 1 merupakan kondisi yang mendekati keadaan sebenarnya di lapangan.

\section{SIMPULAN}

Faktor-faktor yang mempengaruhi bahaya kekeringan secara berurutan adalah: curah hujan, jenis penggunaan lahan, jarak ke sumber air, tekstur tanah, suhu permukaan tanah. Model bahaya kekeringan disusun dengan formulasi: $\mathrm{H}=(0.34 \mathrm{SPI})+(0.20 \mathrm{~L})+(0.19 \mathrm{~B})+(0.17$ Jt)+(0.10 LST). Sepanjang tahun 2003, 2008 dan 2012 telah terjadi kekeringan di wilayah Kabupaten Indramayu. Kekeringan sudah dimulai pada bulan Mei hingga bulan Oktober. Model bahaya kekeringan versi 1 dan versi 2 pada tahun 2003 memiliki luas lahan yang tergolong bahaya tinggi lebih luas daripada tahun 2008 dan 2012. Model versi 1 maupun model versi 2, masing-masing memiliki pola yang sama, yakni tahun 2003 memiliki tingkat keakuratan paling tinggi di awal kemarau dibandingkan yang lainnya. Tahun 2012 akhir kemarau memiliki tingkat keakuratan lebih tinggi dan tahun 2008 memiliki tingkat keakuratan paling rendah. Meskipun model versi 2 memiliki nilai akurasi lebih rendah dari versi 1, model versi 2 merupakan kondisi ideal, dimana keberadaan jaringan irigasi dimaksudkan untuk memenuhi kebutuhan air lahan sawah agar terhindar dari kekeringan, akan tetapi kenyataannya jaringan irigasi kurang berperan pada masa musim kemarau.
Sementara itu, model versi 1 memiliki tingkat validasi yang cukup signifikan terutama pada tahun 2003 dan 2012. Hal ini menunjukkan bahwa versi 1 merupakan kondisi yang mendekati keadaan sebenarnya di lapangan.

\section{DAFTAR PUSTAKA}

Arsyad, S. 2006. Konservasi Tanah dan Air. Ed ke-2. IPB Pr., Bogor.

[BNPB] Badan Nasional Penanggulangan Bencana. 2009. Data Bencana di Indonesia Tahun 2009. BNPB, Jakarta.

[ISDR] International Strategy for Disaster Reduction. 2009. UNISDR Terminology on Disaster Risk Reduction. United Nations, Geneva.

Undang-undang Republik Indonesia Nomor 24 Tahun 2007. 2007. Penanggulangan Bencana. Sekretariat Negara RI. Jakarta.

[UNDP] United Nations Development Programme. 2011. Mainstreaming Drought Risk Management, A Primer. United Nations.

Weng, Q. 2010. Remote Sensing and GIS Integration. Mc Graw Hill, the United State of America.

Wilhite, D.A. 2000. Drought preparedness and response in the context of Sub-Saharan Africa. Journal of Contingencies and Crisis Management.

[WMO] World Meteorologi Organization. 2012. Standardized Precipitation Index, User Guide. WMO-No. 1090, Geneva.

Yang, J., and Y.Q. Wang. 2010. Estimation of land surface temperature using Landsat-7 ETM+ Thermal Infrared and weather station data. Laboratory for Terrestrial Remote Sensing, [internet], [diunduh 2014 Oktober 18]; paper 4. Tersedia www.ltrs.uri.edu/research/LST_page/paper4.doc 